\title{
Decreased stock entering the Belgian Meuse is associated with the loss of colonisation behaviour in yellow-phase European eels
}

\author{
Billy Nzau Matondo* and Michaël Ovidio \\ Laboratory of Fish Demography and Hydroecology, Biology of Behaviour Unit, Freshwater and Oceanic Science Unit of Research \\ (UR-FOCUS), University of Liège,22 Quai E. Van Beneden, B-4020 Liège, Belgium
}

Received 15 May 2017 / Accepted 4 December 2017

Handling Editor: Jérémy Lobry

\begin{abstract}
The upstream migratory behaviour of yellow-phase European eels was investigated in regulated inland rivers $(>320 \mathrm{~km}$ upstream the sea), where the stock is in drastic decline. From 2010 to 2015, eels entering the Belgian Meuse River ( $n=1357$; total length, 231-755 mm) were caught in fish passes, tagged with a pit-tag and released. Their upstream movements were tracked during the next six consecutive years, using three detection stations installed in vertical-slot fish passes of the Meuse and its Ourthe tributary. Among the 1357 eels tagged, 27.6\% $(n=374$ individuals $)$ were detected at one or more of the three upstream detection stations. Only $6.6 \%(n=89)$ of tagged eels were detected at the two subsequent stations. In this last group, most of the detected eels continued to move upstream through the Meuse rather than leaving it for the Ourthe. Water temperature $>13{ }^{\circ} \mathrm{C}$, river flow $24-226 \mathrm{~m}^{3} / \mathrm{s}$, dark time 00:00-05:00 $\mathrm{h}$ and the spring-summer seasons were the most important cues for upstream migration. Temperatures and flows at detection did not differ between size classes of ascending eels, while the detection period was earlier and daily speed was faster in large $(>450 \mathrm{~mm})$ eels. However, small $(\leq 300 \mathrm{~mm})$ eels moved further upstream at slow speeds because they alternated between short periods of movement and long stationary periods. This behaviour suggests the existence of a few nomad individuals and probably more home range dwellers in the entering population. Small eels were better suited to colonise upper rivers.
\end{abstract}

Keywords: Upstream movement / behaviour / body size / speed / yellow-phase eels / freshwater

\section{Introduction}

Many fish species in the world are either or both overexploited and suffer from habitat degradation, and many stocks have collapsed (Zhou et al., 2010). Among them, the emblematic migratory European eel Anguilla anguilla is considered to be outside safe biological limits (ICES, 2013; Dekker and Beaulaton, 2016), and since 2008, the species has been listed as critically endangered on the IUCN Red List of Threatened Species (Jacoby and Gollock, 2014).

The causes of the eel decline include human activities and climate changes in riverine and oceanic ecosystems. The human activities involve physical barriers (hydropower dams, navigation weirs, turbines, pumps) that prevent upstream and downstream migration, habitat loss by river canalisation and wetland drainage, overexploitation and poaching at all life stages, pollution by contaminants and transfer of diseases

\footnotetext{
*Corresponding author: bnmatondo@uliege. be
}

(Belpaire et al., 2009; Dekker and Beaulaton, 2016). The climate changes have influenced the fluctuations in oceanic currents, reproduction success and larval drift (Knights, 2003; Friedland et al., 2007).

The European eel is a diadromous fish species, which spawn in the Sargasso Sea. The transparent, leaf-like larvae, called leptocephali, are transported by oceanic currents and leave after metamorphosing into glass eels and, then, migrate upstream and enter the inland freshwaters and estuarine environments of Europe and North Africa as pigmented elvers (Daverat et al., 2005). In growth zones, these elvers become yellow eels that metamorphose into silver eels, which migrate back downstream, utilising high-fat reserves, through the ocean to the Sargasso Sea, where they reproduce and die (Tesch, 2003).

Yellow eels are found in all water types, from coastal marine waters through to brackish estuaries, in eutrophic and oligotrophic, shallow and deep waters, and throughout rivers, to their upland headwaters (Daverat et al., 2006). During the growth phase, the yellow eel must have access to suitable 
habitats and substantial food resources, for an accumulation of energy reserves useful to complete the eel's reproductive cycle to the Sargasso Sea (Maes et al., 2005; Belpaire et al., 2009). Yellow eels were abundant in many parts of the Belgian Meuse River basin, from low- to upland areas (Baras et al., 1996; Philippart, 2006; Philippart et al., 2010). However, in the Meuse River at Lixhe in Belgium, a drastic decline of upstream migrant yellow eels has been demonstrated. It has been reported that the number of ascending eels in a fishway decreased by $95.5 \%$ in 23 years (Nzau Matondo and Ovidio, 2016). Similarly, the estimated eel stock in the lower part of the Belgian Meuse has dropped from 445000 individuals in 1993 (Baras et al., 1996) to 7184 in 2013 (Nzau Matondo et al., 2017). Concomitantly with declining abundance, the entering migrant eels have increased in body size by $4.1 \mathrm{~mm}$ per year, since 1992 (Nzau Matondo and Ovidio, 2016).

Such a significant reduction in the entering eel stock has raised serious concerns about whether incoming yellow eels will continue to colonise upstream rivers into the Belgian Meuse Basin, far beyond their entry point into Belgium. Similarly, in the context of the stock decline, it is not known whether those larger eels have changed their upstream migration rate. Earlier field works performed outside the framework of the stock decrease, revealed that the upstream migration speeds of eels unaided by tidal transport, were dependent on river current gradient (Aprahamian, 1988), population density pressure (Moriarty, 1986; Ibbotson et al., 2002) and body size of the eels (Clough et al., 2004). For these authors, the low upstream migration rates coincided with the high river current gradient and low density of riverine eels, and the swimming performance increased with increasing eel length. However, such field investigations were rare. Therefore, the longitudinal colonisation behaviour of yellow eels in continental freshwaters remains poorly understood (Feunteun et al., 2003; Laffaille et al., 2004). Analysis involving long-term monitoring at a place where the eel density is very low will help to gain insight on the behaviours guiding the colonisation of the upstream riverine habitats by large eels. A better understanding of the colonisation process of upland rivers is valuable for the development of better, adequate eel management plans, aiming to preserve and restore the stock, particularly in regions distant from the sea, and to meet the silver eel escapement target in the European Commission Eel Recovery Plan (EU, 2007).

Here, we used radio frequency identification (RFID) to track the long-term individual upstream movements of the yellow eels, using automatic transponder detection stations installed in vertical slot fishways. The aim was to investigate the longitudinal colonisation behaviour and activity of the incoming eels in the Belgian Meuse river basin, in an area where the flows are regulated for navigation and hydropower production, and the fishing and consumption of eels are prohibited. Considering the distant location of the study site from estuaries ( $>320 \mathrm{~km}$ upstream from the North Sea) and the stock decline, our study analysed the upstream migratory movement behaviour of various sized eel classes. This analysis involved the percentage of upstream migrants, the colonisation speed, the influence of environmental factors, particularly, the water temperature and flow, period of migration and hour of movement, and the choice of migratory route.

\section{Methods}

\subsection{Study area}

The study was performed in the Meuse River basin (Belgium), $323 \mathrm{~km}$ upstream from the North Sea (Fig. 1). The International Meuse River basin drains a $36000 \mathrm{~km}^{2}$ catchment area, of which a major proportion (nearly a third) is located in Belgium. The source of the Meuse [total length (TL), $925 \mathrm{~km}$ ] lies in France and flows into the North Sea in The Netherlands. A large part of the Meuse is highly artificial, with several dams $(n=46)$ for navigation and hydropower, bank rectification, flow regulation and physicochemical pollution. The Meuse biodiversity is characterised by the presence of nearly 40 fish species, such as the non-native European catfish Silurus glanis, a potential predator for eel and its competitor for resources (Wysujack and Mehner, 2005; Gualtieri et al., 2006; Bevacqua et al., 2011). In this study area, eel has not been subject to effective management measures, such as restocking practices for over two decades (Belpaire et al., 2016).

The study area (Fig. 1) included the Belgian Meuse River, from the hydroelectric dam of Lixhe $(323 \mathrm{~km}$ from the North Sea) to the hydropower and navigation dam of Yvoz-Ramet (31.2 $\mathrm{km}$ upstream from Lixhe). It also included the lower regulated course of the Ourthe tributary (TL, $165 \mathrm{~km}$; catchment area, $3624 \mathrm{~km}^{2}$ ), from its confluence with the Meuse (18.9 km from Lixhe) to the hydropower dam of Angleur (2.3 km from the confluence). The Ourthe is a primary tributary, providing a substantial amount (nearly a third) of the catchment area of the Belgian Meuse and potential growing habitats for the eel. In this study area, free movement of eels and other fish is ensured by new vertical slot fishways (Fig. 1; Tab. 1). There are also three canals (Albert Canal, Liège Canal, Ourthe Canal) and two sluices that offered potential alternate migration routes for the eels (Fig. 1). Several alternative passages can deviate eel from the main route and cause loss of detection (Fig. 1). (i) From the release site, eel can travel upstream to reach the Albert Canal, through the sluice located downstream the first detection station A, (ii) Station B can be bypassed by the ship lock at the Yvoz-Ramet Dam, and (iii) the eels can enter the Ourthe tributary by the Ourthe Canal, without being detected at station $\mathrm{C}$.

The fishways at each hydropower dam had a similar configuration (vertical slot type, Tab. 1). The physicochemical characteristics of the water were similar in the Meuse and the Ourthe, regarding $\mathrm{pH}$ and dissolved oxygen saturation. The Ourthe tributary had a smaller width, colder water and lower flow than the Meuse (Wilcoxon test, $p<0.0001$ ). Within the Meuse, water temperature was significantly higher and flow lower at the upstream station B than at station A (Tab. 1).

\subsection{Tagging, release and monitoring}

A total of 1371 eels (TL: mean $\pm \mathrm{SD}, 415 \pm 62 \mathrm{~mm}$; range, 231-882 $\mathrm{mm}$ ) were collected during their upstream migration, by trapping at the Lixhe fish passes (Fig. 1) from 2010 to 2015 (range, 90-540 eels per year). After capture, the eels were anaesthetised with eugenol $1 / 10$ in alcohol $\left(0.5 \mathrm{~mL} \mathrm{~L}^{-1}\right)$, measured $( \pm 1 \mathrm{~mm})$, weighed $( \pm 1 \mathrm{~g})$ and individually tagged using biocompatible RFID tags (Texas Instruments, HDX, 


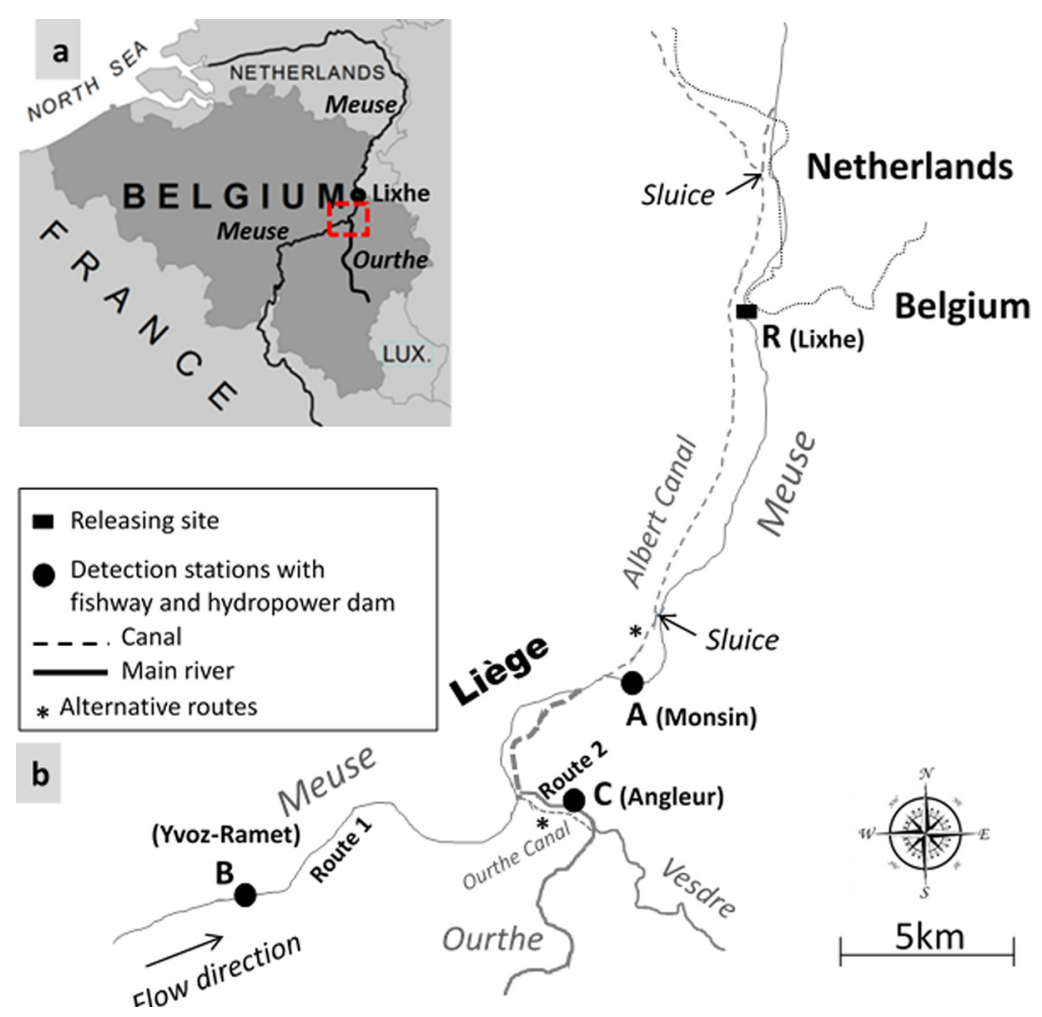

Fig. 1. Map of the study area in the International and Belgian Meuse River basins (a), and location of the catch and release site in the Meuse (at R-Lixhe), the first upstream detection station in the Meuse (A-Monsin), the upstream migration route 1 in the upper Meuse (B-Yvoz-Ramet), the upstream migration route 2 in the Ourthe tributary $(\mathbf{C}-$ Angleur), and the alternative migration routes of yellow-phase eels (the navigable canals of Albert and Ourthe, and the non-navigable Liège Canal) (b).

Table 1. Fishways and daily water physicochemical characteristics at the detection stations from 2010 to 2015.

\begin{tabular}{|c|c|c|c|}
\hline \multirow[b]{2}{*}{ Parameters } & \multicolumn{2}{|c|}{ Meuse River } & \multirow{2}{*}{$\begin{array}{c}\text { Ourthe tributary } \\
\text { C-Angleur }\end{array}$} \\
\hline & A-Monsin & B-Yvoz-Ramet & \\
\hline \multicolumn{4}{|l|}{ a. Pool and vertical slot fishway } \\
\hline Discharge, $\left(\mathrm{m}^{3} \mathrm{~s}^{-1}\right)$ & 0.8 & 0.8 & 0.5 \\
\hline Attraction flow, $\left(\mathrm{m}^{3} \mathrm{~s}^{-1}\right)$ & 4.0 & 3.0 & 1.5 \\
\hline Delta height, (m) & 4.5 & 4.5 & 4.0 \\
\hline Pool size, (length $\times$ width, in $\mathrm{m})$ & variable size $\times 2.5$ & $3.5 \times 2.0$ & $3.5 \times 2.4$ \\
\hline Pool water depth, (m) & 1.5 & 1.5 & $1.5-1.7$ \\
\hline Pool number & 18.0 & 17.0 & 16.0 \\
\hline Slot width, (m) & 0.30 & 0.25 & 0.25 \\
\hline Slot water depth, (m) & 1.3 & 1.3 & 1.2 \\
\hline \multicolumn{4}{|l|}{$\begin{array}{l}\text { b. Physicochemical conditions } \\
\text { (mean, range) }\end{array}$} \\
\hline Locations & $50^{\circ} 39^{\prime} \mathrm{N}-5^{\circ} 37^{\prime} \mathrm{E}$ & $50^{\circ} 35^{\prime} \mathrm{N}-5^{\circ} 27^{\prime} \mathrm{E}$ & $50^{\circ} 36^{\prime} \mathrm{N}-5^{\circ} 36^{\prime} \mathrm{E}$ \\
\hline Temperature, $\left({ }^{\circ} \mathrm{C}\right)$ & $14.4,1.8-27.6$ & $15.4,1.8-28.8$ & $11.5,0.2-26.0$ \\
\hline Flow, $\left(\mathrm{m}^{3} \mathrm{~s}^{-1}\right)$ & $256.3,37.8-2370.1$ & $204.4,31.1-1792.7$ & $51.9,6.3-625.8$ \\
\hline $\mathrm{pH}$ & $8.1,7.5-9.2$ & $8.1,7.2-8.7$ & $8.3,7.4-9.5$ \\
\hline Range dissolved oxygen, $(\%)$ & $92.8,22.0-125.0$ & $93.9,38.0-125.0$ & $97.8,50.0-113.0$ \\
\hline
\end{tabular}


$134.2 \mathrm{kHz}$; size/weight in air: $23 \times 3 \mathrm{~mm} / 0.6 \mathrm{~g}$ ). These tags were inserted into a $2-3 \mathrm{~mm}$-long incision, made using a scalpel in the visceral cavity of the eels (Nzau Matondo et al., 2017). The inserted tags weighed, on average, $0.72 \%$ (range, $0.02-$ $2.14 \%$ ) of the eel's body weight, to meet the best requirement (Jepsen et al., 2002), that is, 2\%. This tagging method was previously tested, by holding 26 eels (TL, $215-441 \mathrm{~mm}$ ) in $1.04 \times 1.04 \times 0.41 \mathrm{~m}$ basins, to evaluate the tag rejection and the induced fish mortality. A perfect retention of the tag $(100 \%$ of the tagged eels), without mortality, was observed at 20 days after tagging, with the incision fully healed.

After tagging, the eels were released into the Meuse River, at a single site located $0.2 \mathrm{~km}$ upstream from the Lixhe Dam, to allow the eels to continue their upstream migration. The eel movements were tracked using RFID detection stations (Cipam ${ }^{\circledR}$, Clermont-Ferrand, France). A rectangular antenna $(0.8 \mathrm{~m}$ wide $\times 1.8 \mathrm{~m}$ deep) was placed in front of the vertical slot upstream from the upper pool of the fishway, at each hydroelectric dam. Eels passing through the antenna were recorded by the station, with associated information on the individual code, date and hour. Two detection stations were placed in the Meuse River, at the first upstream station [A, Monsin (upstream distance from the release site: $13 \mathrm{~km}$ )] and in the upper Meuse [B, Yvoz-Ramet, route 1 (upstream distance from the release site: $31 \mathrm{~km}$ )]. There was also one station located in the Ourthe tributary [C, Angleur, route 2 (upstream distance from the release site: $21 \mathrm{~km}$ )]. Considering the fundamental role of temperature on upstream movements of the eels in regulated rivers, particularly in our study area (Nzau Matondo and Ovidio, 2016), water temperature was continuously recorded at each station, using data loggers (Onset Hobo TidbiT ${ }^{\circledR}$ version 2). Flow data were provided by the Wallonia Public Service of Hydrological Studies.

\subsection{Size classes of the yellow eels}

The captured eels (TL, 231-882 $\mathrm{mm}$ ) were categorised into silver $(n=14)$ and yellow $(n=1357)$ eels. All the silver eels (TL: mean $\pm \mathrm{SD}, 770 \pm 49 \mathrm{~mm}$; range, $708-882 \mathrm{~mm}$ ) were excluded from the analysis. The yellow eels were identified by three morphological descriptors (Pankhurst, 1982; Durif et al., 2005; Nzau Matondo et al., 2017), including the yellow colour of the belly, the absence of a well-defined lateral line and the ocular index $(\mathrm{OI})<6.5$. The eels were also designated as a yellow eel, if only two of the descriptors (most often no lateral line and the OI value) were met. Silver eels had a blackishbrown back and silvery-white belly, a well-defined lateral line and an $\mathrm{OI} \geq 6.5$, according to Pankhurst's silvering threshold value (Pankhurst, 1982). Yellow eels (TL: mean \pm SD, $412 \pm 62 \mathrm{~mm}$; range, $231-755 \mathrm{~mm}$; Fig. 2) were divided into six class sizes $\left(S_{1}-S_{6}\right)$ (Tab. 2). Eels $>450 \mathrm{~mm}$ are considered females, while $<450 \mathrm{~mm}$ may mature to male or female. The median date of tagging was similar for both $S_{5}$ and $S_{6}$, which occurred earlier than $S_{3}$ and later than $S_{1}, S_{2}$ and $S_{4}$. The relationship of length $(L t)$ to weight $(W)$ of the 1357 yellow eels tagged was described by $\log W(\mathrm{~g})=-6.04+3.07 \times \log$ $L t(\mathrm{~mm})\left(R^{2}=0.905\right.$ and $\left.p<0.0001\right)$.

\subsection{Colonisation indicators}

The colonisation behaviour of eels was analysed using several indicators. The rate of ascending eels is defined as the

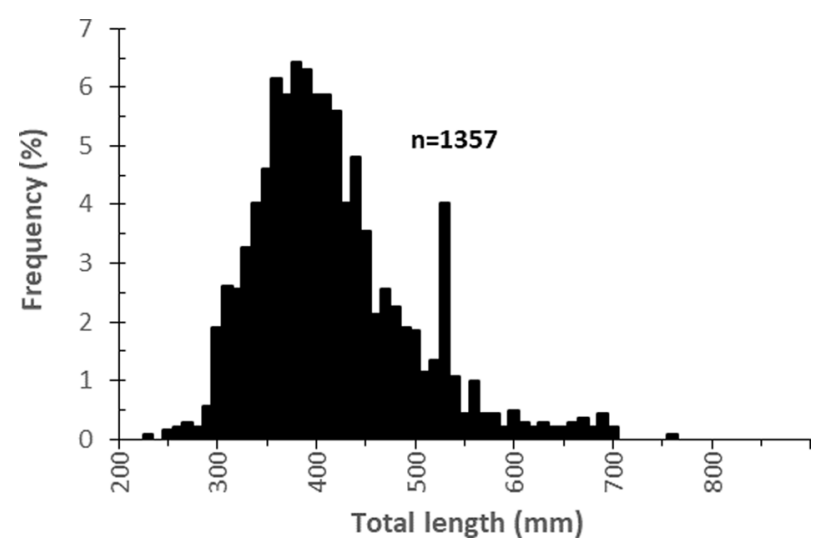

Fig. 2. Length-frequency distribution (10 mm class interval) of yellow eels tagged during the study period from 2010 to 2015 .

proportion (\%) between the number of eels detected and the total number of eels tagged at each detection station. The rate of detections per year is the proportion (\%) between the number of eels detected and the total number of eels tagged each year. The diel activity rhythm is the proportion (\%) between the number of eels detected at a specific hour and the total number of the eels detected over $24 \mathrm{~h}$, at each detection station.

The preferred migration route for the ascending eels was determined, by comparing between the proportion of eels migrating upstream through route 1 at $\mathbf{B}$ in the Meuse River (larger width, higher flow and higher temperature) and the proportion of eels migrating by route 2 at $\mathbf{C}$ in the Ourthe tributary (smaller width, lower flow and lower temperature). For route 1, this was expressed as the number of eels detected at the downstream station $\mathbf{A}$ in the Meuse and then redetected on route 1 at $\mathbf{B}$ in the upper Meuse, divided by the total number of eels detected at $\mathbf{A}$ and then redetected at $\mathbf{B}$ and $\mathbf{C}$ in the Ourthe $(\times 100 \%)$. For route 2 , this was expressed as the number of eels detected at $\mathbf{A}$ in the Meuse and redetected on route 2 at $\mathbf{C}$ in the Ourthe tributary, divided by the total number of eels detected at $\mathbf{A}$ and redetected at $\mathbf{B}$ and $\mathbf{C}(\times 100 \%)$.

For determining the size class of the ascending eels that was the most detected, we used the $D / T$ index, representing the ratio of the number of detected eels divided by the number of tagged eels. We also calculated the $O / A$ index, defined as the ratio of the number of eels detected in their tagging year divided by the number of eels detected after the tagging year.

The relationship between size and water temperature during migration, between size and period and between size and flow were analysed, to understand the effect of the body size of the eel on upstream colonisation behaviour. Similarly, the relation between size and migration speed was tested. The temperature and the flow at detection, the period and the hour of movement, and the migration speed were also described, according to the cumulated seasonal migration percentage of $50 \%$ (P50), 90\% (P90), and the last eels. For the detection period, the maximum duration was also assessed as the time window (days) between the first detected and last detected eel in the year, both, throughout the study period and for each size class of eels. The migration speed of the eels was defined as the distance $(\mathrm{km})$ between the release site and the most upstream detection station divided by the number of days spent on this 
Table 2. Tagging period according to size classes of the tagged yellow eels.

\begin{tabular}{|c|c|c|c|c|c|c|}
\hline \multirow[b]{2}{*}{ Size class } & \multirow[b]{2}{*}{$\mathrm{n}$} & \multirow[b]{2}{*}{$\%$} & \multirow{2}{*}{$\begin{array}{c}\text { Total } \\
\text { length } \\
(\mathrm{mm}) \\
\text { mean } \pm \text { SD }\end{array}$} & \multicolumn{3}{|c|}{ Tagging period } \\
\hline & & & & Median & $90 \%$ (days) & $100 \%$ (days) \\
\hline $\mathrm{S}_{2}(251-300)$ & 36 & 2.7 & $289 \pm 11$ & 18 June & 26 Apr.-10 Aug. (106) & 26 Apr.-27 Aug. (123) \\
\hline $\mathrm{S}_{3}(301-350)$ & 226 & 16.7 & $329 \pm 12$ & 30 June & 28 Apr.-4 Aug. (98) & 26 Apr.-6 Sep. (133) \\
\hline $\mathrm{S}_{6}(>450)$ & 314 & 23.1 & $522 \pm 51$ & 24 June & 27 Apr.-4 Aug. (99) & 22 Apr.-3 Oct. (164) \\
\hline Total & 1357 & 100.0 & $412 \pm 62$ & 23 June & 28 Apr.-1 Aug. (95) & 17 Apr.-3 Oct. (169) \\
\hline
\end{tabular}

route. The relations between these five morphological and environmental variables (body size, temperature, period, flow, speed) were also investigated.

\subsection{Statistical analyses}

The number of detections per station, time after tagging and detection by hour were assessed using Fisher's exact probability $(F E P)$ test. The chi-squared $\left(\chi^{2}\right)$ test was used to compare the upstream distribution of the eels between route 1 (Meuse River) and route 2 (Ourthe tributary), for eels detected in the first upstream station A (Monsin) in the Meuse and redetected most upstream at $\mathbf{B}$ (Yvoz-Ramet) in the upper Meuse or $\mathbf{C}$ (Angleur) in the Ourthe tributary. The body size, water temperature and flow, detection period and migration speed data did not meet a normal distribution (Kolmogorov-Smirnov, $p<0.001)$. For these parameters, comparisons between the six size classes $\left(S_{1}-S_{6}\right)$ of eels were performed using the Kruskal-Wallis $(H)$ test followed by Wilcoxon $(W)$ signed rank. The relations between these five migration variables (body size, temperature, period, flow, speed) were evaluated by Pearson's correlation coefficient. All statistical analyses were deemed significant at $p<0.05$ and were made using the R-Cran project free statistical software package Rcmdr version 2.3-2 (http://www.rproject.org).

\section{Results}

\subsection{Upstream movement dynamics and migration routes}

Of the 1357 yellow eels tagged and released at Lixhe from 2010 to $2015,27.6 \%$ ( $n=374$ individuals $)$ of the eels were detected at one or more of the three upstream detection stations. However, only $6.6 \%(n=89)$ of eels were detected at the two subsequent stations (Tab. 3). Detections of eels decreased with upstream distance from the release site and the time after tagging (Tab. 3). Detections were significantly lower (FEP test, $p<0.0001)$ at the upstream stations [B $(4.9 \%$; $n=66)$ and $\mathbf{C}(3.5 \% ; n=48)]$ than the downstream station (A, $26.2 \% ; n=355)$.

Among the eels detected at a down- and upstream station, $59.6 \%(n=53)$ moved from $\mathbf{A}$ to $\mathbf{B}$ and $40.4 \%(n=36)$ moved from $\mathbf{A}$ to $\mathbf{C}\left(\chi^{2}=6.49, p<0.05\right)$. Few eels $(0.3 \%, n=4)$ were detected further upstream [in route 1 at $\mathbf{B}(0.15 \%)$ and route 2 at $\mathbf{C}(0.15 \%)]$, without being detected at station $\mathbf{A}$.

The detection rates varied between the six initial tagging years, from $12.8 \%$ in 2015 to $58.1 \%$ in 2014 . For each tagging year, detections were higher during the year of tagging and the following year and, then, decreased drastically from the second year onwards (FEP test, $p<0.0001)$. Detections were higher in the year of tagging at $\mathbf{A}(O / A=1.67)$ but were higher after the year of tagging further upstream in $\mathbf{B}(O / A=0.63)$ and $\mathbf{C}$ $(O / A=0.56)$. The $S_{3}-S_{6}$ (eels $>300 \mathrm{~mm}$, detection $\left.>73 \%\right)$ size classes were the most detected at $\mathbf{A}$ (Fig. 3a). In contrast, $S_{1}$ and $S_{2}$ were the most detected size classes further upstream (at $\mathbf{B}$ and $\mathbf{C}$, eels $\leq 300 \mathrm{~mm},>37 \%$ ).

Upstream movements of eels occurred at all times (between 12:00 and 11:00 h, maximum duration $23 \mathrm{~h}$ ); $90 \%$ of eels moved between 00:00 and 05:00 h $(5 \mathrm{~h})$, with the median hour at 3:00 h. At each station, eels migrated mostly (FEP test, $p<0.0001$ ) at night (median hours 2:00-3:00 h; 90 96\% between 00:00 and 05:00 h) (Fig. 3b).

\subsection{Body size and upstream movement}

The size classes most detected were $S_{1}-S_{5}$ (range: $T L$, 200-450 mm, $D / T=0.34-0.50)$ with the highest detection observed in $S_{1}(200-250 \mathrm{~mm}, n=4, D / T=0.5)$ (Fig. 4a). However, $S_{1}$ (the smallest sized eels) did not include a sufficient number of eels, making an objective interpretation difficult. In contrast, $S_{6}$ (the largest sized eels, $>450 \mathrm{~mm}, D / T$, 0.23 ) was the least detected, and it was mostly detected during the year of tagging $(O / A=3.24)$ (Fig. 4b). $S_{4}(351-400 \mathrm{~mm}, O /$ $A=1.09)$ and $S_{5}(401-450 \mathrm{~mm}, O / A=1.16)$ showed similar numbers for both, the eels detected in the year of tagging and the eels detected after the tagging year. $S_{2}(251-300 \mathrm{~mm}, O /$ $A=0.18)$ and $S_{3}(301-350 \mathrm{~mm}, O / A=0.71)$ showed a lower number of eels detected in the year of tagging than those observed after the tagging year. $S_{1}(200-250 \mathrm{~mm}, O / A=0)$ was only detected after the tagging year.

\subsection{Body size, water temperature, migration period and river flow}

Detections occurred at water temperatures between 13.8 and $27.6{ }^{\circ} \mathrm{C}$, and $90 \%$ of the eels were detected between 19.0 
Table 3. Number of eels detected each year according to the date of initial tagging. TL is the total length of yellow eels; $\mathbf{C}$ indicates the mean daily water temperature of the full year; range dates in brackets show the time window of tagging and release of the eels; and $\mathbf{A}, \mathbf{B}$ and $\mathbf{C}$ correspond to the detection stations on the Meuse River (A, B) and the Ourthe tributary (C); total percentage in brackets is the proportion (\%) between the total number of eels detected over the years at all stations and the total number of eels tagged for each initial tagging year.

\begin{tabular}{|c|c|c|c|c|c|c|c|c|c|c|}
\hline \multirow{3}{*}{$\begin{array}{l}\text { Year of } \\
\text { initial } \\
\text { tagging }\end{array}$} & \multicolumn{2}{|c|}{ Number of eels tagged } & \multirow[b]{3}{*}{ Station } & \multicolumn{7}{|c|}{ Number of yellow eels detected } \\
\hline & \multirow[b]{2}{*}{ Total } & \multirow{2}{*}{$\begin{array}{c}\text { Yellow eels } \\
\text { (TL in } \mathrm{mm}: \\
\text { mean } \pm \mathrm{SD} \\
\text { range }\end{array}$} & & \multicolumn{6}{|c|}{ Number of years after tagging } & \multirow[b]{2}{*}{ Total } \\
\hline & & & & 0 & 1 & 2 & 3 & 4 & 5 & \\
\hline 2010 & 100 & 100 & & & & & & & & $(24.0 \%)$ \\
\hline (18 Jun. to & & $(390 \pm 42)$ & $\mathrm{A}\left(14.1^{\circ} \mathrm{C}\right)$ & 21 & 1 & 2 & - & - & - & 24 \\
\hline \multirow[t]{2}{*}{$28 \mathrm{Jul})}$. & & $(247-591)$ & $\mathrm{B}\left(15.1^{\circ} \mathrm{C}\right)$ & - & - & - & - & - & - & - \\
\hline & & & $\mathrm{C}\left(10.8^{\circ} \mathrm{C}\right)$ & - & - & - & - & - & - & - \\
\hline 2011 & 221 & 221 & & & & & & & & $(20.8 \%)$ \\
\hline (22 Apr. to & & $(390 \pm 57)$ & $\mathrm{A}\left(15.5^{\circ} \mathrm{C}\right)$ & 9 & 8 & 8 & 1 & 2 & - & 28 \\
\hline \multirow[t]{2}{*}{3 Oct.) } & & $(231-690)$ & $\mathrm{B}\left(16.7^{\circ} \mathrm{C}\right)$ & - & 2 & 8 & - & - & - & 10 \\
\hline & & & $\mathrm{C}\left(12.1^{\circ} \mathrm{C}\right)$ & - & 4 & 2 & 2 & - & - & 8 \\
\hline 2012 & 374 & 369 & & & & & & & & $(41.7 \%)$ \\
\hline (11 May to & & $(420 \pm 67)$ & $\mathrm{A}\left(14.1^{\circ} \mathrm{C}\right)$ & 45 & 50 & 12 & 1 & - & - & 108 \\
\hline \multirow[t]{2}{*}{10 Sep.) } & & $(281-755)$ & $\mathrm{B}\left(15.1^{\circ} \mathrm{C}\right)$ & 12 & 16 & 3 & 2 & - & - & 33 \\
\hline & & & $\mathrm{C}\left(11.1^{\circ} \mathrm{C}\right)$ & 2 & 4 & 5 & 2 & - & - & 13 \\
\hline 2013 & 380 & 374 & & & & & & & & $(29.4 \%)$ \\
\hline (25 Apr. to & & $(419 \pm 59)$ & $\mathrm{A}\left(13.6^{\circ} \mathrm{C}\right)$ & 35 & 40 & 7 & - & - & - & 82 \\
\hline \multirow[t]{2}{*}{13 Sep.) } & & $(293-690)$ & $\mathrm{B}\left(14.5^{\circ} \mathrm{C}\right)$ & 8 & 10 & - & - & - & - & 18 \\
\hline & & & $\mathrm{C}\left(10.8^{\circ} \mathrm{C}\right)$ & - & 9 & 1 & - & - & - & 10 \\
\hline 2014 & 215 & 215 & & & & & - & - & - & $(58.1 \%)$ \\
\hline (17 Apr. to & & $(408 \pm 44)$ & $\mathrm{A}\left(14.9^{\circ} \mathrm{C}\right)$ & 89 & 14 & - & - & - & - & 103 \\
\hline \multirow[t]{2}{*}{25 Aug.) } & & $(302-698)$ & $\mathrm{B}\left(15.8^{\circ} \mathrm{C}\right)$ & 5 & - & - & - & - & - & 5 \\
\hline & & & $\mathrm{C}\left(12.0^{\circ} \mathrm{C}\right)$ & 12 & 5 & - & - & - & - & 17 \\
\hline 2015 & 81 & 78 & & & & - & - & - & - & $(12.8 \%)$ \\
\hline (26 May to & & $(434 \pm 59)$ & $\mathrm{A}\left(14.3^{\circ} \mathrm{C}\right)$ & 10 & - & - & - & - & - & 10 \\
\hline \multirow[t]{2}{*}{$30 \mathrm{Jul}$.) } & & $(329-618)$ & $\mathrm{B}\left(15.2^{\circ} \mathrm{C}\right)$ & - & - & - & - & - & - & - \\
\hline & & & $\mathrm{C}\left(12.0^{\circ} \mathrm{C}\right)$ & - & - & - & - & - & - & - \\
\hline Total & 1371 & $\begin{array}{c}1357 \\
(412 \pm 58) \\
(231-755)\end{array}$ & $\begin{array}{c}\mathrm{ABC} \\
\left(13.8^{\circ} \mathrm{C}\right)\end{array}$ & 248 & 163 & 48 & 8 & 2 & - & $\begin{array}{c}469 \\
(34.6)\end{array}$ \\
\hline
\end{tabular}

and $26.2^{\circ} \mathrm{C}$, with the median at $22.7^{\circ} \mathrm{C}$. Temperatures at movements did not differ significantly between the six size classes of eels (median temperatures $\left({ }^{\circ} \mathrm{C}\right), S_{1}=21.0, S_{2}=22.6$, $S_{3}=23.3, S_{4}=22.7, S_{5}=23.1$ and $S_{6}=22.3$ ) (H test: $d f=5$, $H=9.6847, p=0.08468, n=433$ ) (Fig. 5a). Among the three detection stations, temperatures of upstream migratory movements were significantly lower at $\mathbf{C}$ (median temperature $=$ $\left.19.3^{\circ} \mathrm{C}\right)$ in the Ourthe tributary than at $\mathbf{A}\left(22.9^{\circ} \mathrm{C}\right)$ and $\mathbf{B}$ $\left(23.9^{\circ} \mathrm{C}\right)$ in the Meuse River (H test: $d f=2, H=94.705$, $\left.p=2.2 \times 10^{-16}, n=433\right)\left(\right.$ range $W=0-3, p=2.274 \times 10^{-12}$ $\left.4.547 \times 10^{-13}\right)$.

From 2010-2015, detection occurred between 18 April and 27 August (131 days). In total, 90\% of eels were detected between 7 June and 14 August (68 days), with the median date of 8 July. The detection period varied significantly between the size classes of the eels ( $\mathrm{H}$ test: $d f=5, H=16.364, p=0.005879$, $n=432)$. Among the size classes, $S_{1}(200-250 \mathrm{~mm}$; median date, 29 June) and $S_{6}$ (>450 mm; 4 July) were detected earlier than $S_{2}$ (251-300 mm; 8 July), $S_{3}$ (301-350 mm; 9 July), $S_{4}$ (351-400 mm; 16 July) and $S_{5}(301-350 \mathrm{~mm} ; 23$ July) (range $\left.W=615-1681, p=4.678 \times 10^{-3}-6.497 \times 10^{-4}\right)($ Fig. 5b).

Detections occurred at river flows between 9.7 and $361.4 \mathrm{~m}^{3} \mathrm{~s}^{-1}$, and $90 \%$ of the eels were detected between 23.7 and $226.3 \mathrm{~m}^{3} \mathrm{~s}^{-1}$, with the median at $95.1 \mathrm{~m}^{3} \mathrm{~s}^{-1}$. Flows during movements did not differ significantly between the six size classes of eels (median flows $\left(\mathrm{m}^{3} \mathrm{~s}^{-1}\right), S_{1}=90.8$, $S_{2}=115.8, S_{3}=94.5, S_{4}=95.8, \mathrm{~S}_{5}=95.2$ and $\left.S_{6}=84.8\right)(\mathrm{H}$ test: $d f=5, H=2.082, p=0.8377, n=433)$. Among the three detection stations, flows at movements were significantly lower at $\mathbf{C}$ (median flow $=23.6 \mathrm{~m}^{3} \mathrm{~s}^{-1}$ ) in the Ourthe tributary than at $\mathbf{B}\left(96.9 \mathrm{~m}^{3} \mathrm{~s}^{-1}\right)$ and $\mathbf{A}\left(99.9 \mathrm{~m}^{3} \mathrm{~s}^{-1}\right)$ in the Meuse River ( $\mathrm{H}$ test: $d f=2, H=112.47, p<2.2 \times 10^{-16}$, $n=433)\left(W=0, p=4.547 \times 10^{-13}\right)$. These flows accounted for less than half the average daily flow of the Ourthe tributary at C (45\%) and the Meuse River at A (39\%) and B $(47 \%)$. 

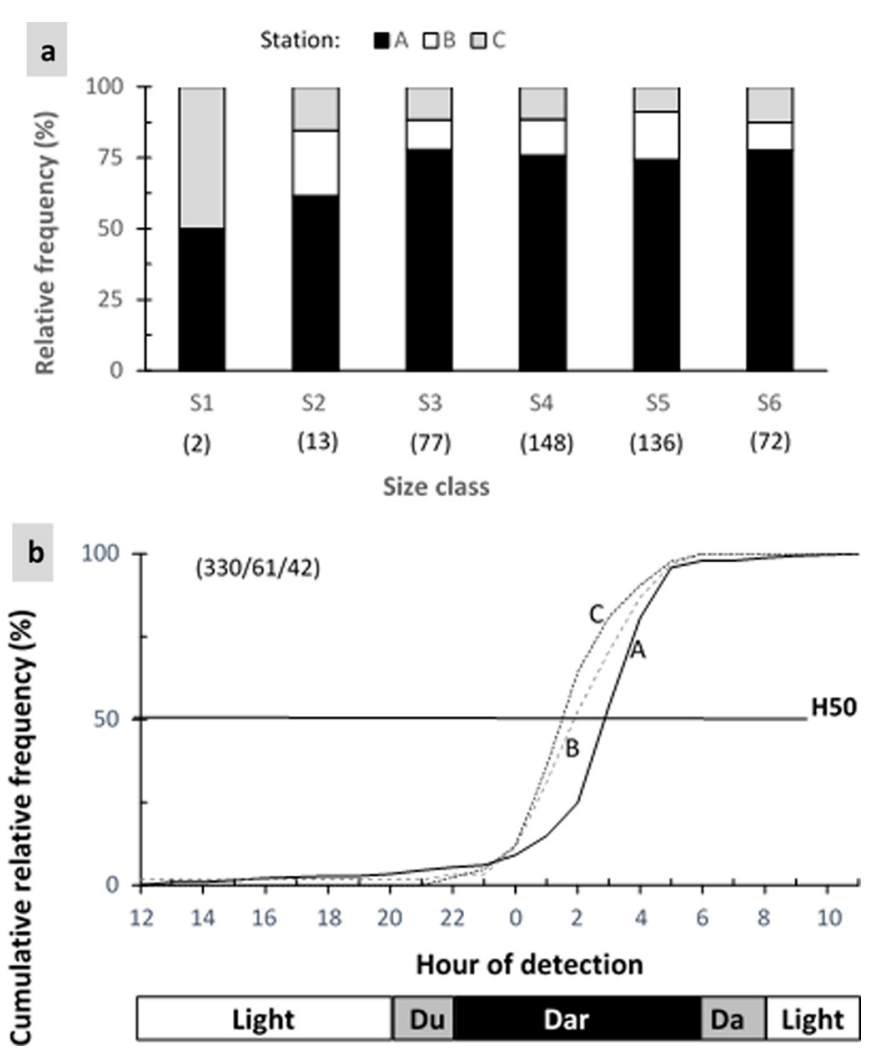

Fig. 3. Frequencies of ascending yellow eels according to size classes (a) and hour of detection (b). H50 indicates the hour of detection of $50 \%$ (median) of the eels; $\mathbf{A}, \mathbf{B}$ and $\mathbf{C}$ specify detection stations at the first upstream detection station A (Monsin) in the Meuse, B (YvozRamet) on route 1 in the upper Meuse, and $\mathbf{C}$ (Angleur) on route 2 in the Ourthe tributary. Numbers in brackets indicate the sample size of eels detected by size classes and stations $\mathbf{A}, \mathbf{B}$ and $\mathbf{C}$, respectively. Du and Dar correspond to dusk and dawn, respectively.

\subsection{Body size and migration speed}

Eels migrated upstream at speeds between 0.012 and $6.5 \mathrm{~km} \mathrm{day}^{-1}$; and $90 \%$ of eels moved between 0.019 and $2.167 \mathrm{~km} \mathrm{day}^{-1}$, with a median speed of $0.317 \mathrm{~km}$ day $^{-1}$. The daily travel speed differed significantly between the size classes of eels (H test: $d f=5, H=40.021, p=1.479 \times 10^{-7}$, $n=429)$. The fastest size class was $S_{6}(>450 \mathrm{~mm}$, median speed, $\left.0.650 \mathrm{~km} \mathrm{day}^{-1}\right)$, followed by $S_{5}(401-450 \mathrm{~mm}$, $\left.0.325 \mathrm{~km} \mathrm{day}^{-1}\right)$ and $S_{4}\left(351-400 \mathrm{~mm}, 0.228 \mathrm{~km} \mathrm{day}^{-1}\right)($ range $W=13-1617, \quad p=1447 \times 10^{-2}-1609 \times 10^{-7}$ ) (Fig. 6). In contrast, $\quad S_{1} \quad\left(200-250 \mathrm{~mm}, \quad 0.015 \mathrm{~km} \mathrm{day}^{-1}\right), \quad S_{2} \quad(251-$ $\left.300 \mathrm{~mm}, 0.038 \mathrm{~km} \mathrm{day}^{-1}\right)$ and $S_{3}(301-350 \mathrm{~mm}, 0.08 \mathrm{~km}$ day $^{-1}$ ) were the slowest size classes.

\subsection{Relations between migration variables analysed}

Between the five migration variables analysed, water temperature was not correlated with river flow and body length while it was positively correlated with detection period (Pearson correlations: $r=0.36, p<0.0001$ ) and daily speed $(r=0.12, p=0.0113)$. Speed was not correlated with period, but it was positively correlated with body length $(r=0.21$,

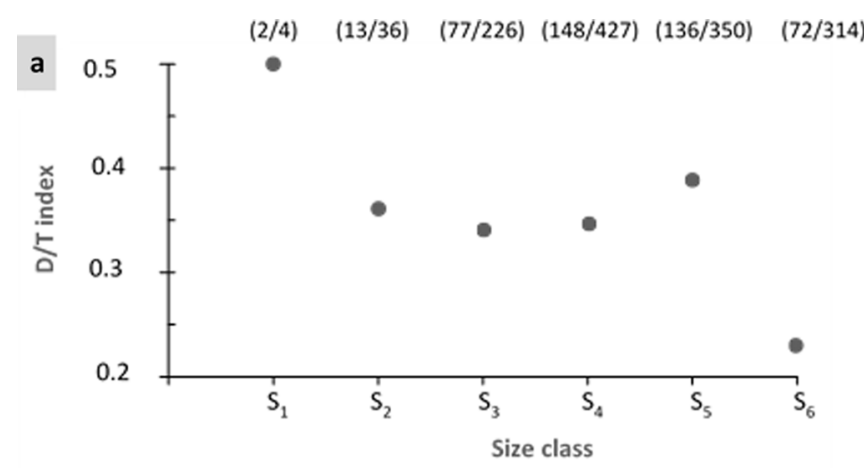

$\mathrm{S}_{1}: 200-250 \mathrm{~mm} \quad \mathrm{~S}_{3}: 301-350 \mathrm{~mm} \quad \mathrm{~S}_{5}: 401-450 \mathrm{~mm}$ $\mathrm{S}_{2}: 251-300 \mathrm{~mm}_{4}: 351-400 \mathrm{~mm} \quad \mathrm{~S}_{6}:>450 \mathrm{~mm}$

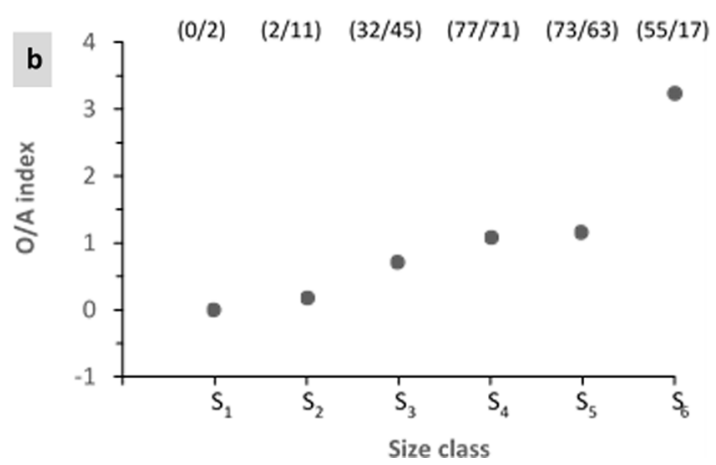

Fig. 4. $D / T$ (a) and $O / A$ indices (b) per size class of tagged yellow eels. The numbers in brackets show the sample sizes of eels detected and eels tagged for the $D / T$ index, and the sample sizes of eels detected in the tagging year and eels detected after the tagging year for the $O / A$ index.

$p<0.0001)$ and inversely correlated with flow $(r=-0.17$, $p=0.0005)$. Period was negatively correlated with body length $(r=-0.15, p=0.002)$ and flow $(r=-0.14, p=0.0038)$. Body length was not correlated with flow. These correlations highlighted the importance of water temperature conditions in upstream migration process and body size in daily speed in the study site.

\section{Discussion}

Using RFID detection stations, we described the upstream migratory movement behaviours of various eel body size classes in the Belgian Meuse River, which is regulated for hydropower generation and navigation, and, in which, the stock of the incoming eels has drastically declined (Nzau Matondo and Ovidio, 2016). The detection systems were placed in fish-passes, allowing us to follow the upstream movements of the natural immigrant eels over long distances and for six consecutive years, thus, producing accurate information about the eel's migration behaviour. As the tags have an infinite lifespan, monitoring upstream migration behaviour can be conducted over many consecutive years. Our results indicated that the species, despite its poor swimming capacities (Porcher, 2002; Baudoin et al., 2015), could move upstream through vertical slot fishways during the riverine 

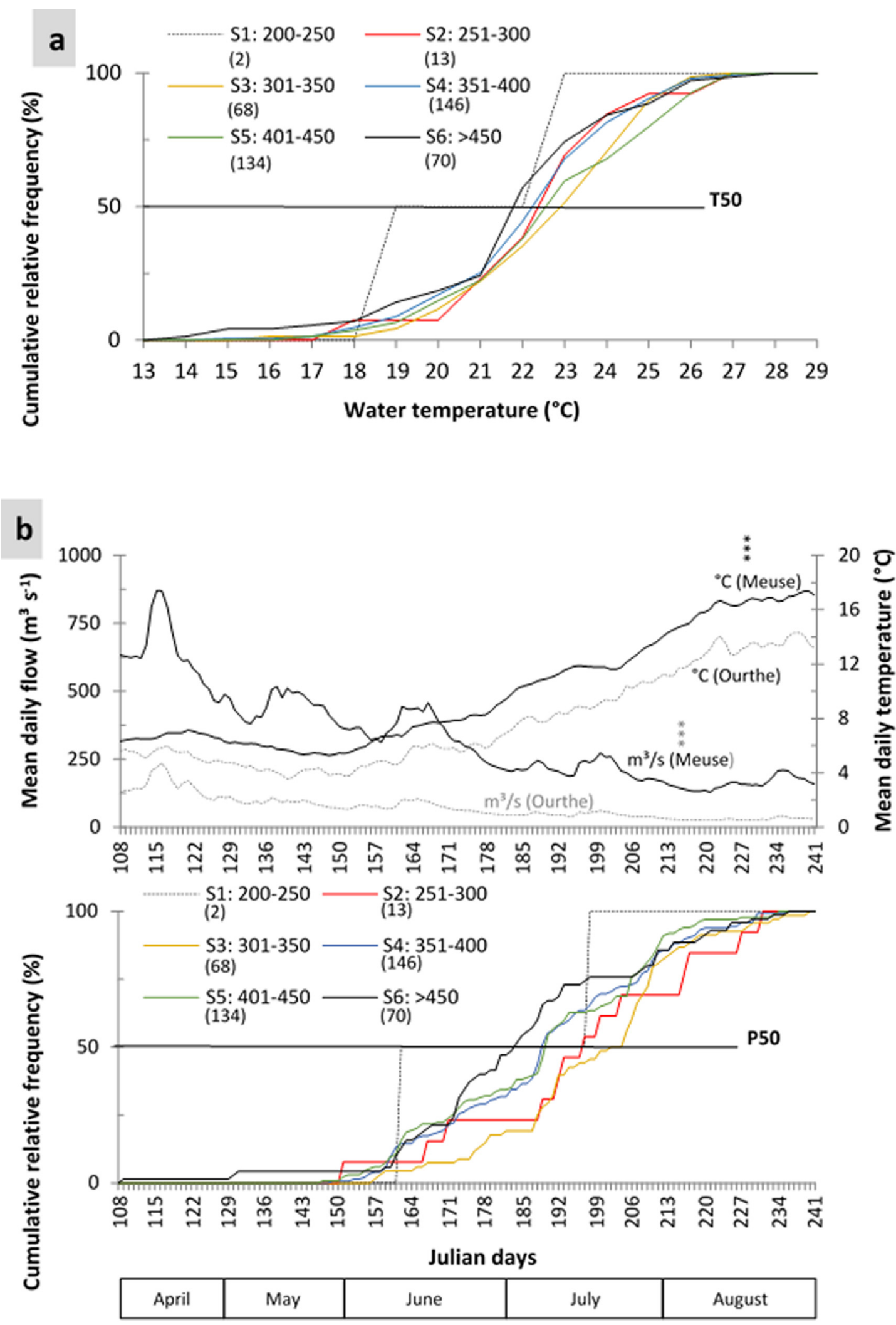

Month

Fig. 5. Water temperature at detection (a) and detection period (b) relative to the mean daily temperature and flow of the Meuse River and the Ourthe tributary during the study period from 2010 to 2015 . Numbers in brackets indicate the sample size of the size classes $\left(S_{1}-S_{6}\right.$, in mm) of eels for temperature and period. T50 and P50 indicate medians for temperature and period, respectively. 


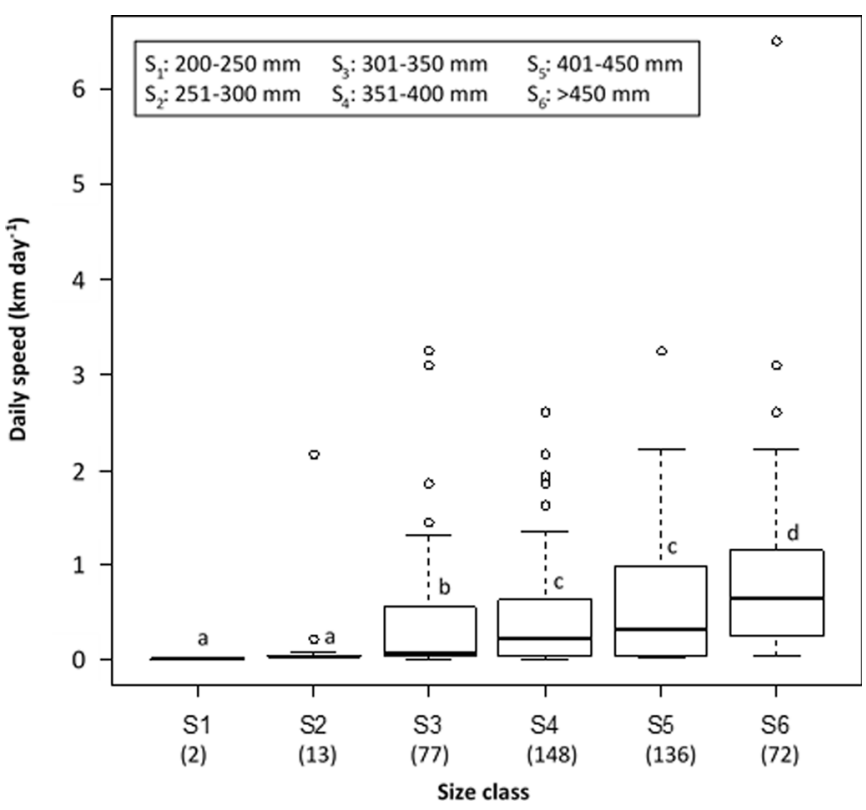

Fig. 6. Relations between the size classes of eels and the daily travel speeds. Numbers in brackets indicate the sample size of the eels detected. Values are medians, 5th, 25th, 75th and 95th percentiles; the bar marks the median and circles indicate outliers. Size classes marked with the same letter are not significantly different $(\mathrm{H}$ and $W$ tests, $p<0.05)$.

colonisation. However, the real efficiency of the fishways, regarding the passage success for the ascending yellow-phase eels, remains unknown at our study site. These fishways were optimised for salmonids (e.g., Atlantic salmon Salmo solar, sea trout Salmo trutta) and large potamodromous (rheophilic) fish (e.g., barbel Barbus barbus, chub Squalius cephalus) that have better swimming capacities than eels (Porcher, 2002; Baudoin et al., 2015).

We demonstrated the further upstream detection of about $27.6 \%$ of the tagged yellow eels belonging to all size classes, at stations distant (up to $31 \mathrm{~km}$ ) from the release site, but only $6.6 \%$ of the eels were detected at two subsequent RFID stations. These findings suggest the existence of a small proportion of "nomads" (or "emigrations"), searching for more suitable habitats in the upstream direction. There were also, probably, a majority of "home range dwellers", eels that establish in a given area for between several months to several years. Feunteun et al. (2003) and Laffaille et al. (2005) described such categories of behaviours, which were associated with the high behavioural plasticity of yellow eels. These two distinct movement behaviours of eels occur after their first year or even during their second year in rivers (Feunteun et al., 2003). These movements may be explained by habitat shifts according to size (Baisez, 2001) or attributed to variations in environmental conditions, such as floods, water levels, temperature and human disturbance (Lamothe et al., 2000). These categories followed the "founder" and the "pioneer" strategies that prevail in the youngest stages (glass eels and elvers) during their first year in rivers (Feunteun et al., 2003; Laffaille et al., 2005). The small rate of nomadic behaviour among the eels entering Belgium underlines the near disappearance of colonisation of the upper tributaries in the
Belgian Meuse River basin, which had once been intense (Baras et al., 1996). This outcome suggests that the upper part of the basin will be progressively emptied by the progressive departure of the oldest individuals at the silver stage. To repopulate the upper part of the basin, a well-targeted stocking, using glass eels and very young eels $\leq 300 \mathrm{~mm}$, might succeed (Ovidio et al., 2015; Brämick et al., 2016; Josset et al., 2016; Pedersen and Rasmussen, 2016), but the success of downstream migration of these restocked eels remains an important topic.

Among the tagged yellow eels, the larger eels (size class $S_{6}$ ) were detected earlier and moved faster than the other size classes. This tendency could be related to their detection occurring mostly in the year of tagging $(O / A=3.24)$ and their large size (mean length, $522 \mathrm{~mm}$ ). However, their upstream colonisation activity $(D / T=0.23)$ was very low. This observation could be due to the ecological and behavioural profile of large eels. Previous studies showed that $S_{6}$ eels were $>6$ years old (Mazel et al., 2012) and mostly female eels, which were more prone to settle and feed before silvering and downstream migration (Aprahamian, 1988; Durif et al., 2005; Laffaille et al., 2006). The eels $>450 \mathrm{~mm}$ were females, with reduced upstream migratory activity and are recognised in the literature as being capable of growing to a larger size and living for longer in freshwaters than male eels (De Leo and Gatto, 1995; Ibbotson et al., 2002; MacNamara and McCarthy, 2014). Other studies have also shown that the large yellow eels might adopt a highly sedentary lifestyle, even at periods of the year where this developmental stage usually shows upstream movements (Baras et al., 1998; Laffaille et al., 2005; Ovidio et al., 2013). $S_{1}$ and $S_{2}$ (eels $\leq 300 \mathrm{~mm}$ ) were mostly detected after the tagging year $(O / A<0.2)$ and showed a higher detection $(>37 \%)$ at further upstream stations compared to the other size classes. The eels $\leq 300 \mathrm{~mm}$ were, therefore, better fitted to colonise the upper rivers in habitats farther from the sea. $S_{3}, S_{4}$ and $S_{5}$ (eels $>300 \mathrm{~mm}$ and $\leq 450 \mathrm{~mm}$ ) displayed an intermediate detection profile, with a nearly similar number of the eels detected in the year of tagging and after the tagging year $(O / A=0.70-1.16)$.

Several hypotheses can be envisaged to explain why $72.4 \%$ of the tagged yellow eels were never detected upstream of the capture site. (i) Some eels might have reached the upper rivers without being detected, because of alternative migration routes (ship locks and navigation canals, Fig. 1) present in the study site. This behaviour probably occurred, but only for a few individuals, as only $0.3 \%$ of the tagged eels were detected further upstream in rivers without being detected downstream at the first upstream station, (ii) The tagged yellow eels were still dwelling close to the point of release because of sufficient availability of growing habitats, resulting from the low eel densities in the Meuse River with long-term reduction in the eel recruitment (Nzau Matondo and Ovidio, 2016). The tagged yellow eels had a mean size of $412 \mathrm{~mm}$, meaning these eels displayed an ecological profile, with a preference for deeper habitats as the main feeding and resting sites (Baisez, 2001; Laffaille et al., 2003, 2004), which were abundant in the Meuse near our release site. In comparison, the lower eel densities in the Meuse likely produces sedentary behaviour. Various markrecapture studies have also revealed a limited home range from the original tagging sites on the freshwater yellow-phase eels over an extended period (up to 7 years) (Baisez, 2001; 
Laffaille et al., 2005), (iii) Handling mortality and RFID tag rejection by the yellow eels could be greater in the fields than in captivity, where perfect retention (100\% of the tagged eels) of the tag and no mortality were observed in our previous test. However, Laffaille et al. (2005) reported $14 \%$ of the tags were rejected within $1 \mathrm{~h}$ after RFID tagging in trials, but that further tag loss rate was meagre (Feunteun et al., 2000; Baisez, 2001), (iv) Probable natural mortality in the tagged yellow eels and predation by piscivorous fish species, such as the European catfish. Eels have been found in stomachs of catfish competing for food and space, as both species are predators feeding near the bottom in confined environments (Wysujack and Mehner, 2005; Gualtieri et al., 2006). Baisez (2001) reported that the natural mortality of eels is rather low (about of $5-10 \%$ per year) in the field, (v) Possible biases related to the detection sites chosen, which were only located in fishways because of the difficulties of installing such detection systems in the navigable canals and locks. Such a design might lead to an underestimation of the detection success.

The upstream movements of the detected eels were observed in spring and summer at water temperatures $>13{ }^{\circ} \mathrm{C}$ and during the darkness. Our observations are consistent with previous observations on anguillids at this life stage (Tesch, 2003; Nzau Matondo et al., 2017). However, the use of RFID telemetry provided more precision about the dates $(90 \%$ of eels between 7 June and 14 August), the water temperatures (90\% from $\left.19.0-26.2^{\circ} \mathrm{C}\right)$ and the time $(90 \%$ between $00: 00$ and 05:00 h), during which, the upstream colonisation activity is high for the riverine yellow eels. Such knowledge may be useful in the implementation of eel conservation actions, such as the seasonal maintenance of migration routes, the timing and duration of the eel trapping, as well as river flow management during the peak of the eel migration. Our RFID tracking device indicated that the nomadic eels preferred to continue upstream through the large river (Meuse) rather than leave at the first tributary (Ourthe). The low colonisation rate of eels through the Ourthe tributary could be explained by its significantly lower temperature than the Meuse, which was probably less attractive for growth and swimming activity. The effect of low temperatures was noticed in this study, by the absence of migration activity at $<13^{\circ} \mathrm{C}$. This observation was consistent with the accepted limits of $10-15^{\circ} \mathrm{C}$, for the beginning of migration in the eels (Naismith and Knights, 1988; White and Knights, 1997). The choice of the Meuse could result from the combined action of environmental factors, such as higher temperature associated with a higher rate flow and lower current speed, which are more attractive for upstream movements of eels (Nzau Matondo and Ovidio, 2016; Santos et al., 2016; Nzau Matondo et al., 2017). This is also supported by the importance of water temperature conditions in upstream migration process as highlighted in the correlation between migration parameters. In the case of our study area, upstream movements of eels increase when water temperature conditions increase and flow regimes decrease.

We observed a significant positive relationship between the body size of eels and the daily migration speed, which is consistent with the findings of Clough et al. (2004). However, this association did not include the actual size of the eels detected after the year of tagging, because they were not recaptured. From the apparent maximum migration season (18
April-27 August, 131 days), $S_{6}(>450 \mathrm{~mm})$, the fastest size class eels, could potentially travel a median distance of $85.2 \mathrm{~km}$ per year. In contrast, the travelled distance decreased to only 2 and $5 \mathrm{~km}$ per year for the slowest classes of eels $S_{1}$ (200-250 mm) and $S_{2}(251-300 \mathrm{~mm})$, respectively. In these slowest eels, migrations were the result of intermittently switching between brief swimming activity and long stationary periods (e.g., feeding or resting activity) rather than long continuous swimming movement at very slow speed. By pooling all migration speed data of the eels (median speed, $0.317 \mathrm{~km} \mathrm{day}^{-1}$ or $0.004 \mathrm{~m} \mathrm{~s}^{-1}$ ), the annual distance travelled was estimated to be about $41.5 \mathrm{~km}$. This estimate was much higher than those assessed in previous field studies of European eel migrations in riverine systems (Aprahamian, 1988: Dee River in Wales, $10-20 \mathrm{~km}_{\text {year }}{ }^{-1}$ and Severn River in England, 20-30 $\mathrm{km}$ year ${ }^{-1}$ ). The higher migration rate in the Meuse River could correlate with its low river current gradient $(80 \mathrm{~m} / 230 \mathrm{~km})$. According to Aprahamian (1988), the low migration rate of eels is related to a more arduous migration, resulting from the steeper gradient of the rivers, such as the Dee River. However, according to typical swimming speed of one body length per second (Hart and Reynolds, 2008), this translates to $0.4 \mathrm{~m} \mathrm{~s}^{-1}$ for these eels (mean length, $413 \mathrm{~mm}$ ), suggesting that they are relatively slow. However, it should be noted that these eels have already travelled $>320 \mathrm{~km}$ from the sea.

\section{Conclusion}

We have presented upstream migration behaviour of various size classes of yellow eels in the upland river of the Meuse, $>320 \mathrm{~km}$ from the sea. Our 6 year study indicates most eels were home range dwellers and that small eels $(\leq 300 \mathrm{~mm})$ moved further upstream than larger eels. These data will be useful for freshwater managers when developing strategies aimed at reducing the risk of collapse of the local eel stock in inland rivers and at meeting the silver eel escapement target in river systems with low natural recruitment.

Acknowledgements. The authors express their thanks to A. Dierckx, J.P. Benitez and G. Rimbaud for their participation in the fieldwork and SETHY-MET of Wallonia Public Service (SPW) for the environmental data. We also extend our thanks to anonymous reviewers whose suggestions strengthened the paper. This study was funded by the "Stock abundance estimation of wild yellow eels recruited by upstream migration in the Meuse River of Wallonia and implementation of restocking tests using glass eels and elvers" project funded by the European Fisheries Fund (FEP No. 32-1102-002) and represented by X. Rollin and F. Fontaine.

\section{References}

Aprahamian MN. 1988. Age structure of eel, Anguilla anguilla (L.), populations in the River Severn, England and the River Dee, Wales. Aquacult Fish Manage 19: 365-375.

Baisez A. 2001. Optimisation des suivis des indices d'abondances et des structures de taille de l'anguille européenne (Anguilla anguilla, L.) dans un marais endigué de la côte atlantique: relations espècehabitat, $\mathrm{PhD}$ thesis, University of Toulouse, Toulouse, France, pp. 396. 
Baras E, Philippart JC, Salmon B. 1996. Estimation of migrant yellow eels stock in large rivers through the survey of fish passes: a preliminary in the River Meuse (Belgium), in: I.G. Cowx (Ed.), Stock Assessment in Inland Fisheries, Oxford Fishing news books (Blackwell), London, UK, pp. 314-325.

Baras E, Jeandrain D, Serouge B, Philippart JC. 1998. Seasonal variations in time and space utilization by radio-tagged yellow eels Anguilla anguilla (L.) in a small stream. Hydrobiologia 371/372: 187-198.

Baudoin JM, Burgun V, Chanseau M, Larinier M, Ovidio M, Sremski W, Steinbach P, Voegtle B. 2015. Assessing the passage of obstacles by fish. Concepts, design and application, The ICE protocol for ecological continuity, Onema, France, 200 p.

Belpaire CGJ, Goemans G, Geeraerts C, Quataert P, Parmentier K, Hagel P, De Boer J. 2009. Decreasing eel stocks: survival of the fattest? Ecol Freshw Fish 18: 197-214.

Belpaire C, Thuyne GV, Breine J, Buysse D, Wichelen JV, Coeck J, Ovidio M, Nzau Matondo B, Meyer JD, Bouillart M, Adrianes D, Verhelst P, Rees JF, Rollin X, Vlietinck K. 2016. Report on the eel stock, fishery and other impacts in Belgium 2016, In Joint EIFAAC/ICES/GFCM WGEEL Report 2016, pp. 113-152.

Bevacqua D, Andrello M, Melià P, Vincenzi S, De Leo G, Crivelli A. 2011. Density-dependent and inter-specific interactions affecting European eel settlement in freshwater habitats. Hydrobiologia 671: 259-265.

Brämick U, Fladung E, Simon J. 2016. Stocking is essential to meet the silver eel escapement target in a river system with currently low natural recruitment. ICES J Mar Sci 73: 91-100.

Clough SC, Lee-Elliott IE, Turnpenny AWH, Holden SDJ, Hinks C. 2004. Swimming speeds in fish: phase 2, R\&D Technical Report W2-049/TR1, 93 p.

Daverat F, Tomas J, Lahaye M, Palmer M, Elie P. 2005. Tracking continental habitat shifts of eels using otolith $\mathrm{Sr} / \mathrm{Ca}$ ratios: validation and application to the coastal, estuarine and riverine eels of the Gironde-Garonne-Dordogne watershed. Mar Freshw Res 56: 619-627.

Daverat F, Limburg KE, Thibault I, Shiao J-C, Dodson J, Caron F, Tzeng W-N, Iizuka Y, Wickström H. 2006. Phenotypic plasticity of habitat use by three temperate eel species, Anguilla anguilla, A. japonica and A. rostrata. Mar Ecol Prog Ser 308: 231-241.

Dekker W, Beaulaton L. 2016. Climbing back up what slippery slope? Dynamics of the European eel stock and its management in historical perspective. ICES J Mar Sci 73: 5-13.

De Leo GA, Gatto M. 1995. A size and age-structured model of the European eel (Anguilla anguilla L.). Can J Fish Aquat Sci 52: 1351-1367.

Durif C, Dufour S, Elie P. 2005. The silvering process of Anguilla Anguilla: a new classification from the yellow resident to the silver migrating stage. J Fish Biol 66: 1025-1043.

EU. 2007. Establishing measures for the recovery of the stock of European eel. Council regulation (EC) no 1100/207 of 18 September 2007. Off J Eur Union L248: 17-23.

Feunteun E, Acou A, Laffaille P, Legault A. 2000. European eel (Anguilla anguilla): prediction of spawner escapement from continental population parameters. Can J Fish Aquat Sci 57: $1627-1635$.

Feunteun E, Laffaille P, Robinet T, Briand C, Baisez A, Olivier JM, Acou A. 2003. A review of upstream migration and movements in inland waters by anguillid eels: toward a general theory, in: $\mathrm{K}$. Aida, K. Tsukamoto, K. Yamauchi (Eds.), Eel Biology, SpringerVerlag, Tokyo, Japan, pp. 191-213.

Friedland KD, Miller MJ, Knights B. 2007. Oceanic changes in the Sargasso Sea and declines in recruitment of the European eel. ICES J Mar Sci 64: 519-530.
Gualtieri M, Mecatti M., Diodato F. 2006. Growth of European catfish (Silurus glanis L.) in Florence province (Central Italy) and management proposals. Freshw Biol 34: 287-291.

Hart PJB, Reynolds JD. 2008. Handbook of fish biology and fisheries, Volume 1 Fish Biology, Blackwell Publishing company, 432 p.

Ibbotson A, Smith J, Scarlett P, Aprahamian MW. 2002. Colonisation of freshwater habitats by the European eel Anguilla anguilla. Freshw Biol 47: 1696-1706.

ICES. 2013. Report of the Joint EIFAAC/ICES Working Group on Eels (WGEEL), 3-9 September 2012, Copenhagen, Denmark, ICES CM 2013/ACOM:18, 824224 p.

Jacoby D, Gollock M. 2014. Anguilla anguilla. In: IUCN2014. IUCNRed List of Threatened Species. Version 2014. 1. www.iucnredlist.org

Jepsen N, Koed A, Thorstad EB, Baras E. 2002. Surgical implantation of telemetry transmitters in fish: how much have we learned? Hydrobiologia 483: 239-248.

Josset Q, Trancart T, Mazel V, Charrier F, Frotté L, Acou A, Feunteun E. 2016. Pre-release processes influencing short-term mortality of glass eels in the French eel (Anguilla anguilla, Linnaeus 1758) stocking programme. ICES J Mar Sci 73: 150-157.

Knights B. 2003. A review of the possible impacts of long-term oceanic and climate changes and fishing mortality on recruitment of anguillid eels of the Northern Hemisphere. Sci Total Environ 310: 237-244.

Laffaille P, Feunteun E, Baisez A, Robinet T, Acou A, Legault A, Lek S. 2003. Spatial organisation of European eel (Anguilla anguilla L.) in a small catchment. Ecol Freshw Fish 12: 254-264.

Laffaille P, Baisez A, Rigaud C, Feunteun E. 2004. Habitat preferences of different European eel size classes in a reclaimed marsh: a contribution to species and ecosystem conservation. Wetlands 24: 642-651.

Laffaille P, Acou A, Guillouet J. 2005. The yellow European eel (Anguilla anguilla L.) may adopt a sedentary lifestyle in inland freshwaters. Ecol Freshw Fish 14: 191-196.

Laffaille P, Acou A, Guillouet J, Mounaix B, Legault A. 2006. Patterns of silver eel (Anguilla anguilla L.) sex ratio in a catchment. Ecol Freshwat Fish 15: 583-588.

Lamothe PJ, Gallagher M, Chivers DP, Moring JR. 2000. Homing and movement of yellow-phase Americain eels in freshwater ponds. Environ Biol Fish 58: 393-399.

MacNamara R, McCarthy TK. 2014. Silver eel (Anguilla anguilla) population dynamics and production in the River Shannon, Ireland. Ecol Freshw Fish 23: 181-192.

Maes GE, Raeymaekers JAM, Pampoulie C, Seynaeve A, Goemans G, Belpaire C, Volckaert FAM. 2005. The catadromous European eel Anguilla anguilla (L.) as a model for freshwater evolutionary ecotoxicology: relationship between heavy metal bioaccumulation, condition and genetic variability. Aquat Toxicol 73: 99-114.

Mazel V, Charrier F, Robinet T, Laffaille P. 2012. Using lengthfrequency analysis to determine the age of Anguilla anguilla (L.). J Appl Ichthyol 28: 655-657.

Moriarty C. 1986. Riverine migration of young eels Anguilla anguilla (L.). Fish Res 4: 43-58.

Naismith IA, Knights B. 1988. Migrations of elvers and juvenile European eels, Anguilla anguilla L., in the River Thames. J Fish Biol 33: 161-175.

Nzau Matondo B, Ovidio M. 2016. Dynamics of upstream movements of the European eel Anguilla anguilla in an inland area of the River Meuse over the last 20 years. Environ Biol Fish 99: 223-235.

Nzau Matondo B, Benitez JP, Dierckx A, Philippart JC, Ovidio M. 2017. Assessment of the entering stock, migration dynamics and fish pass fidelity of European eel in the Belgian Meuse River. River Res Appl 33: 292-301. 
Ovidio M, Seredynski A, Philippart JC, Nzau Matondo B. 2013. A bit of quiet between the migrations: the resting life of the European eel during their freshwater growth phase in a small stream. Aquat Ecol 47: 291-301.

Ovidio M, Tarrago-Bès F, Nzau Matondo B. 2015. Short-term responses of glass eels transported from UK to small Belgian streams. Ann Limnol - Int J Lim 51: 219-226.

Pankhurst NW. 1982. Relation of visual changes to the onset of sexual maturation in the European eel, Anguilla anguilla L. J Fish Biol 21: 417-428.

Pedersen MI, Rasmussen GH. 2016. Yield per recruit from stocking two different sizes of eel (Anguilla anguilla) in the brackish Roskilde Fjord. ICES J Mar Sci 73: 158-164.

Philippart JC. 2006. L'érosion de la biodiversité : les poissons. Université de Liège, Belgique, 306 p.

Philippart JC, Ovidio M, Rimbaud G, Dierckx A, Poncin P. 2010. Bilan des observations sur les populations de l'anguille dans les sous-bassins hydrographiques Meuse aval, Ourthe, Amblève et
Vesdre, Commission provinciale de Liège du Fonds piscicole du Service Public de Wallonie, Belgique, $161 \mathrm{p}$.

Porcher JP. 2002. Fishways for eels. Bull Fr Pêche Piscicult 364: 147-155.

Santos JM, Rivaes R, Oliveira J, Ferreira MT. 2016. Improving yellow eel upstream movements with fish lifts. $J$ Ecohydraul 1: $50-61$.

Tesch FW. 2003. The eel, in: J.E. Thorpe (Ed.), Blackwell Science, Oxford, UK, $416 \mathrm{p}$.

White EM, Knights B. 1997. Environmental factors affecting migration of the European eel in the Rivers Severn and Avon, England. J Fish Biol 50: 1104-1116.

Wysujack K, Mehner T. 2005. Can feeding of European catfish prevent cyprinids from reaching a size refuge? Ecol Freshw Fish 14: 87-95.

Zhou S, Smith ADM, Punt AE, Richardson AJ, Gibbs M, Fulton EA, Pascoe S, Bulman C, Bayliss P, Sainsbury K. 2010. Ecosystembased fisheries management requires a change to the selective fishing philosophy. Proc Natl Acad Sci 107: 9485-9489.

Cite this article as: Nzau Matondo B, Ovidio M. 2018. Decreased stock entering the Belgian Meuse is associated with the loss of colonisation behaviour in yellow-phase European eels. Aquat. Living Resour. 31: 7 